\title{
Survey on issues concerning eHealth and telemedicine in Wound Care
}

Ciro Falasconi, Vincenzo Amalfi, Patrizia Baroni, Giovanni Vito Corona, Corrado Maria Durante, Paola Fanin, Caterina Favaro, Massimo Fornaciari, Alessandro Farris, Manuela Galleazzi, Francesco Giacinto, Giorgio Guarnera, Vincenzo Lauletta, Mario Marazzi, Marco Masina, Vincenzo Mattaliano, Giovanni Battista Mosti, Giuseppe Nebbioso, Francesco Stanganello, Francesco Petrella

Italian Association of Skin Ulcers, Turin, Italy

\section{INTRODUCTION}

In the three months period between March and June 2016 we launched a survey on the AUIC website, open to the contribution of all members, to evaluate the dissemination and use of modern information technology in the treatment of Chronic Skin Lesions (CSL).

The now ubiquitous diffusion of desktop and portable computers and mobile devices such as smartphones and tablets has confirmed the World Wide Web ("the Internet") as a tool for communication and sharing of information and knowledge. With the current daily use of the Internet and the advent of social media there are no longer any limits to communication in all social and employment contexts.

In our view, it is clear that the world of wound care could, or rather should, use these important tools in order to improve the standards of care offered to patients on a daily basis. In addition, the entry of a new generation of "digital natives" in the labor market will make the use of these technologies no longer an exception, but the most absolute normality.
Correspondence: Italian Association of Skin Ulcers, Via San Francesco da Paola 37, 10123 Turin, Italy.

Tel: +39.011.2446911 - Fax: +39.011.2446950

E-mail: info@aiuc.it

Key words: E-health; Telemedicine; Survey; Italian Association of Skin Ulcers.

Received for publication: 31 December 2016.

Accepted for publication: 7 March 2017.

This work is licensed under a Creative Commons Attribution NonCommercial 4.0 License (CC BY-NC 4.0).

(C) Copyright C. Falasconi et al., 2017

Licensee PAGEPress, Italy

Italian Journal of Wound Care 2017; 1(1):27-33

doi:10.4081/ijwc.2017.4

\section{MATERIALS AND METHODS}

The survey was carried out using the SurveyMonkey platform which presented a questionnaire with 25 multiple choice questions to participating members. The questionnaire, which required about 15 minutes, was anonymous and there was no way to trace the data of the participants.

\section{RESULTS}

Ninety-one members filled out the survey. Most of them $(80 \%)$ use computers in their workplace, with a very clear preference for the Windows environment (Figure 1).

Of the participants $75 \%$ use medical records for the storage of patients' clinical data with an even distribution between traditional (paper-based) and digital media (51\% vs. 52\% respectively) (Figure 2).

Nearly $90 \%$ of the participants use digital tools (operating mainly in the Android environment) in their clinical practice (smartphones, tablets and cameras), but these tools are almost always personal (not provided by the employer) and therefore not devoted exclusively to work activities (Figure 3).

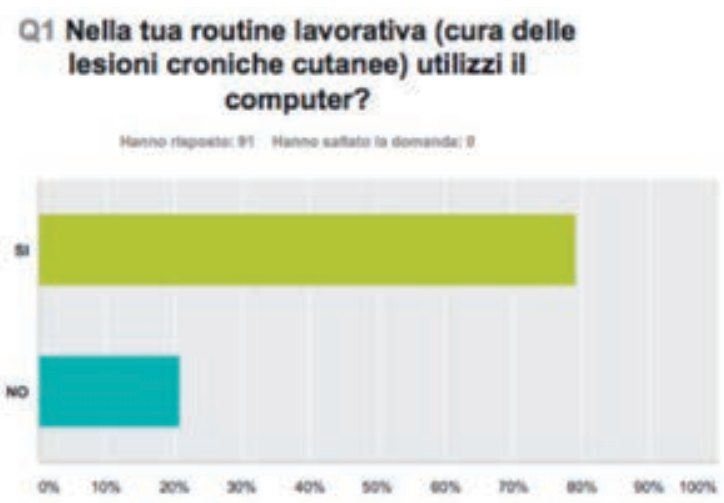

Figure 1. Q1 In you workplace routine (treatment of chronic skin lesions) do you use a computer? (91 answered, 0 skipped the question) YES/NO. 
The archiving of clinical images is the main purpose for which these digital tools are used and these images end up occupying up to $50 \%$ of the device's memory space in $70 \%$ of cases (Figure 4 ).

Concerning the interactions with patients, both conventional (telephone or personal contact) and modern technologies (PC, smartphone or tablet) are used, with a large preference for personal or telephone contact. About $45 \%$ of participants also use SMS, email or social media, WhatsApp being the most favored (Figure 5).

Concerning the communication among colleagues or with other medical personnel, both within the working group or when requesting external advice, telephone and personal contact are once again the most popular modes. However, the use of digital tools such as SMS, email or WhatsApp is more common in this area of communication than in communication directly with the patient. It is important to consider that some (less than 10\%) still use traditional communication "on paper" (Figure 6).

In more than $90 \%$ of cases there is no use of digital platforms dedicated to telemedicine to communicate clinical data but, rather, we see the use of the tools mentioned above (which can also be used for other purposes, even personal ones) (Figure 7).

About $85 \%$ of participants document the healing progression of the CSL in their care using an evaluation of photographs without taking specific measurements.

In approximately $90 \%$ of cases, operators have no tools to document the care management cost of those CSL.

The informed consent for the management of clinical data is collected in approximately $60 \%$ of cases, mostly $(80 \%)$ by archiving a paper copy (Figure 8 ).

Almost all participants are convinced that greater use of modern digital communication technologies can help

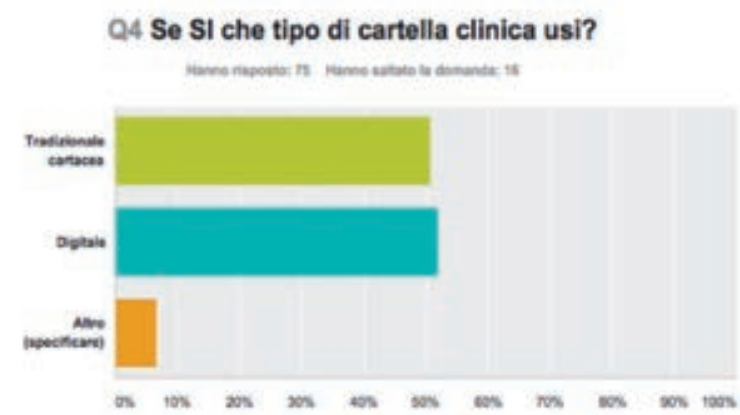

Figure 2. Q4 If YES, what type of medical record do you use? (75 answered, 16 skipped the question) Traditional paper-based, Digital, Other (specify). them better manage the care of patients suffering from CSL (Figure 9).

\section{CONCLUSIONS}

Participants in the survey show a traditional approach that uses mostly conventional tools like paper or digital folders (on PC).

However, the interest in new technologies is clear; not having work-dedicated tools certainly reduces their use, but those who use them, despite everything, show a real conviction that such tools are useful to improve their clinical practice and allow them to save time if nothing else.

The archiving of digital clinical images and the ability to share them very quickly is probably the most appealing aspect of modern technology. This is perfectly in line with

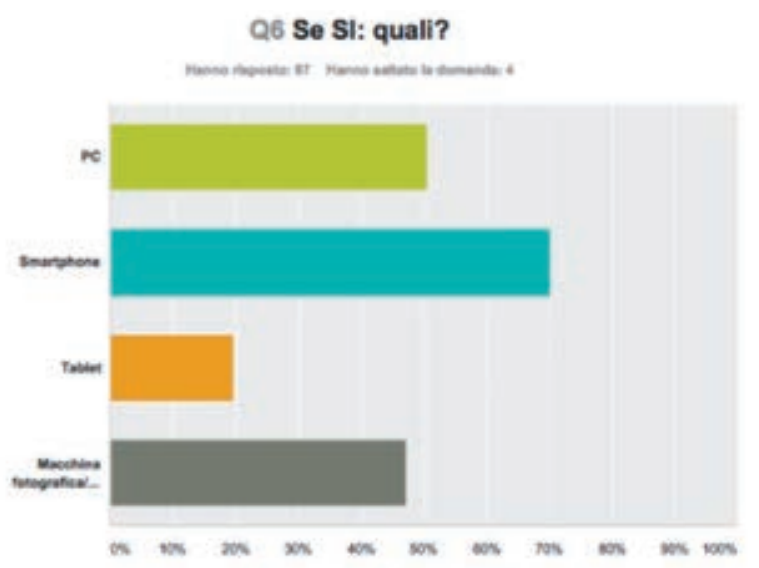

Figure 3. Q6 If YES, which type? (87 answered, 4 skipped the question) PC, Smartphone, Tablet, Camera.

\section{Q11 Per quale motivo utilizzi supporti} digitali?

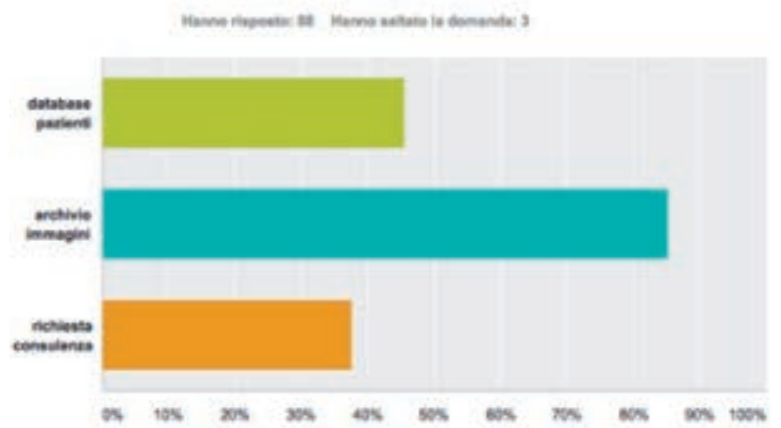

Figure 4. Q11 For what purpose do you use digital supports? (88 answered, 3 skipped the question) Patient database, Images archive, Request for advice. 


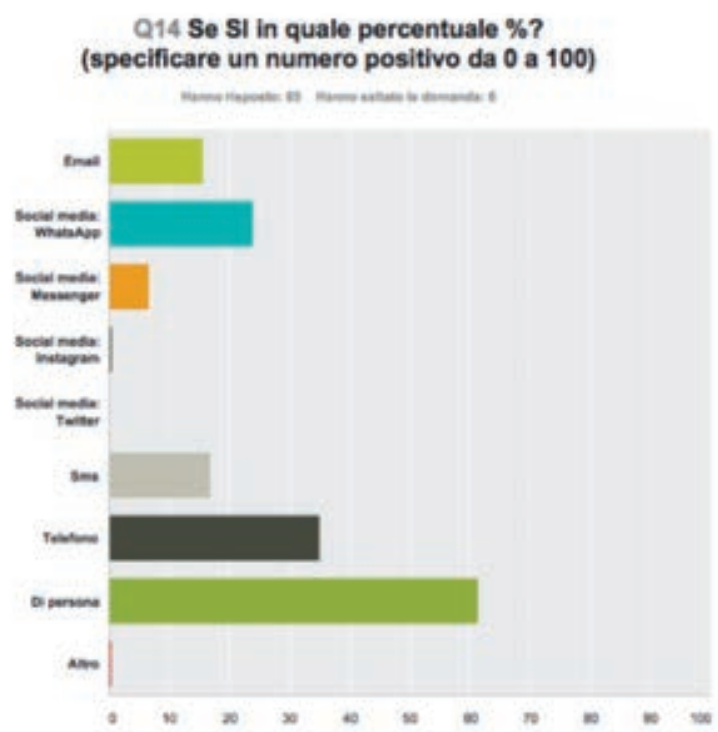

Figure 5. Q14 If YES, in what percentage? (specify a whole number between 0 and 100) ( 85 answered, 6 skipped the question) Email, Social Media: WhatsApp, Social Media: Messenger, Social Media: Instagram, Social Media: Twitter, SMS, Phone, In person, Other.

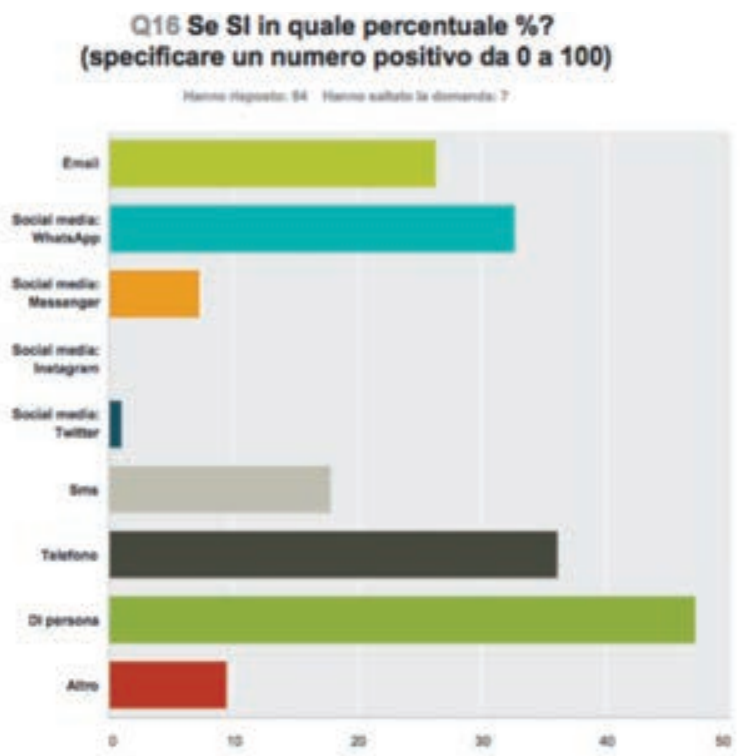

Figure 6. Q16 If YES, in what percentage (specify a whole number between 0 and 100) (84 answered, 7 skipped the question) Email, Social Media: WhatsApp, Social Media: Messenger, Social Media: Instagram, Social Media: Twitter, SMS, Phone, In person, Other.

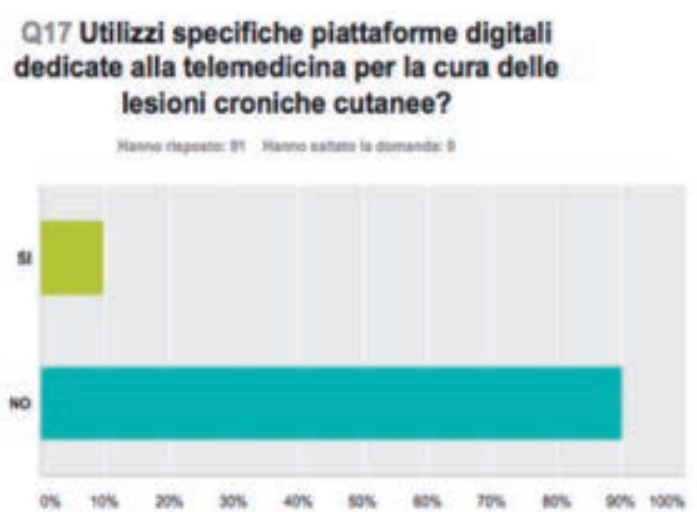

Figure 7. Q17 Do you use specific digital platforms dedicated to telemedicine for the treatment of chronic skin lesions? (91 answered, 0 skipped the question) YES/NO.

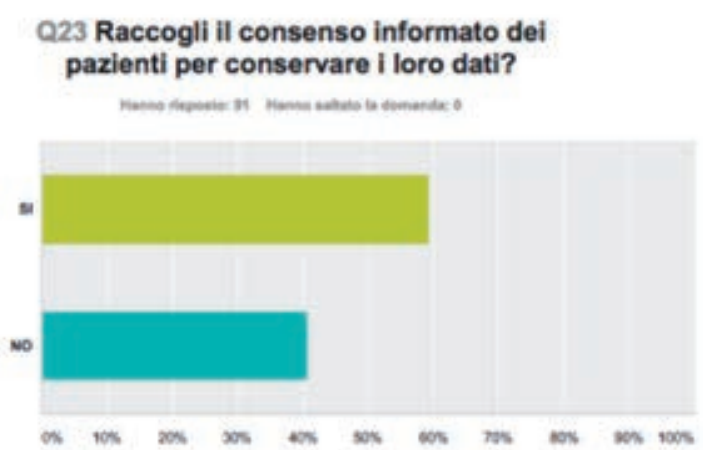

Figure 8. Q23 Do you collect the patients' informed consent to store their data? (91 answered, 0 skipped the question) YES/NO.

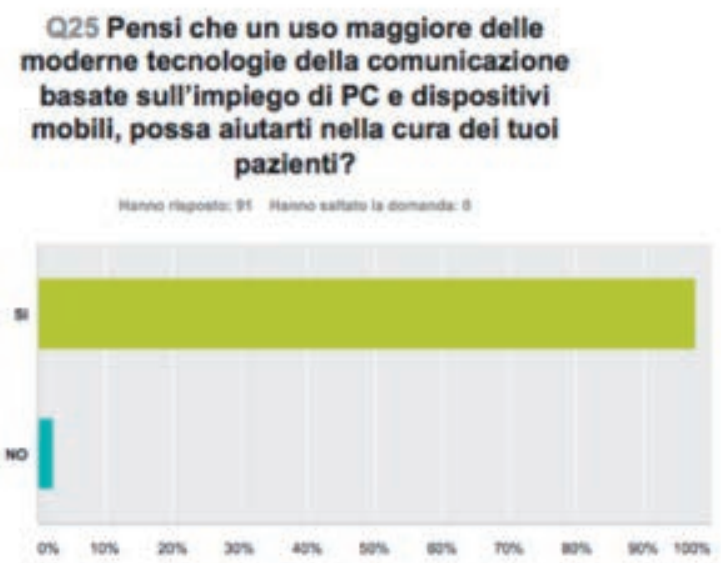

Figure 9. Q25 Do you think that greater use of modern communication technology based on the use of computers and mobile devices can help in the care of your patients? (91 answered, 0 skipped the question) YES/NO. 
modern and popular cultural trends but exposes such sensitive data to poor protection risks. In fact, the insufficient diffusion of digital platforms dedicated to telemedicine creates a mix of clinical and personal data mainly on personal laptops, with an inability to respect the patients' privacy as dictated by current regulations on privacy protection.

The collection of informed consent for the management of clinical data is limited to $60 \%$ of the cases, which shows a tendency not to comply with the current regulations on this subject.
The survey reveals a lack of dissemination of tools for the objective assessment of morphological variations of the CSL for the immediate use by medical personnel, and a lack of tools that can archive and evaluate their management cost which can also be used by administrators.

The results of this survey indicate that the world of wound care has a widespread need for "modern" and "smart" tools that can improve and enrich this kind of clinical activity. 


\section{Indagine conoscitiva sui temi della eHealth e della telemedicina nel Wound Care}

Ciro Falasconi, Vincenzo Amalfi, Patrizia Baroni, Giovanni Vito Corona, Corrado Maria Durante, Paola Fanin, Caterina Favaro, Massimo Fornaciari, Alessandro Farris, Manuela Galleazzi, Francesco Giacinto, Giorgio Guarnera, Vincenzo Lauletta, Mario Marazzi, Marco Masina, Vincenzo Mattaliano, Giovanni Battista Mosti, Giuseppe Nebbioso, Francesco Stanganello, Francesco Petrella

Associazione Italiana Ulcere Cutanee

\section{INTRODUZIONE}

Nel trimestre marzo-giugno 2016 abbiamo avviato sul sito AIUC una indagine conoscitiva, aperta al contributo di tutti i soci, per valutare la diffusione e l'impiego delle moderne tecnologie dell'informazione nella cura delle Lesioni Croniche Cutanee (LCC).

La diffusione, ormai ubiquitaria, di computer fissi e portatili e di dispositivi mobili come smartphone e tablet ha determinato la assoluta affermazione del World Wide Web ("la rete") come strumento di comunicazione e condivisione di informazioni e conoscenza: con l'attuale impiego quotidiano di Internet e con l'avvento dei "Social Media" non esistono più limiti alla comunicazione in tutti gli ambiti sociali e lavorativi.

È evidente, secondo noi, che anche il mondo del Wound Care possa o, addirittura, debba, utilizzare questi importanti mezzi per migliorare gli standard di cura che offre ogni giorno ai suoi pazienti. Inoltre, l'avvicinarsi al mondo del lavoro delle nuove generazioni di "nativi digitali" renderà l'impiego di tali tecnologie non più una eccezione, ma la più assoluta normalità.

\section{MATERIALI E METODI}

L'indagine è stata realizzata utilizzando la piattaforma SurveyMonkey e somministrando ai soci che volevano partecipare un questionario con 25 domande a risposta multipla. La compilazione del questionario, che richiedeva un tempo di circa 15 minuti, è stata realizzata in forma anonima e in nessun modo è possibile risalire ai dati dei partecipanti.

\section{RISULTATI}

Hanno risposto alla survey 91 soci. Gran parte di questi $(80 \%)$ utilizza il computer nel proprio ambito lavorativo, con una nettissima preferenza per l'ambiente Windows (Figura 1).

Il 75\% dei partecipanti utilizza cartelle cliniche per la archiviazione dei dati clinici dei pazienti, con una distri- buzione equa fra supporti tradizionali (di tipo cartaceo) e digitali (51 vs. 52\%, rispettivamente) (Figura 2).

Quasi il 90\% dei partecipanti impiega strumenti digitali, che operano prevalentemente in ambiente Android, nella propria pratica clinica (smartphone, tablet e macchine fotografiche), ma tali strumenti sono quasi sempre personali (non forniti dal datore di lavoro) e, pertanto, non dedicati esclusivamente alle attività lavorative (Figura 3).

La archiviazione di immagini di tipo clinico rappre-

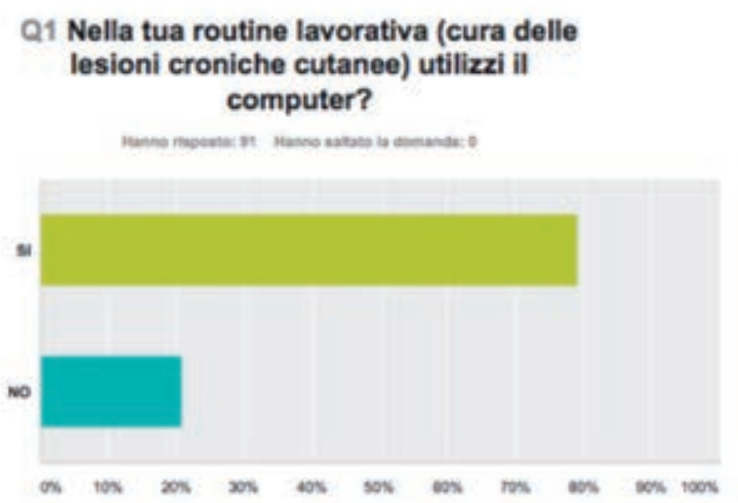

Figura 1.

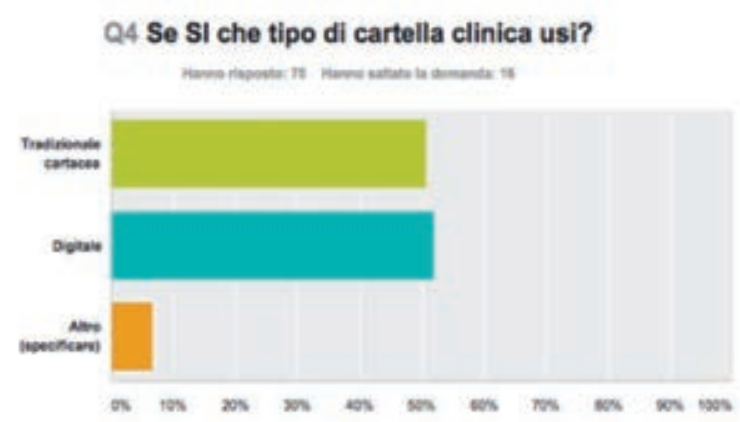

Figura 2. 
senta lo scopo principale per il quale tali strumenti digitali sono utilizzati e queste immagini finiscono per occupare, nel $70 \%$ dei casi, fino al $50 \%$ dello spazio di memoria del dispositivo stesso (Figura 4).

Per quanto riguarda le modalità di interazione con $\mathrm{i}$ pazienti, sono utilizzate sia modalità di tipo tradizionale (via telefono o contatto personale) che le moderne tecnologie (tramite PC, smartphone o tablet), con ampia preferenza per il contatto personale o vocale, telefonico. Circa il $45 \%$ dei partecipanti utilizza anche gli SMS, la posta elettronica o i social media, fra i quali WhatsApp è il preferito (Figura 5).

Nella comunicazione fra colleghi o con altro personale sanitario, sia all'interno del gruppo di lavoro che per richiesta di consulenza esterna, il telefono o il contatto personale rappresentano sempre le modalità più diffuse. Tuttavia l'impiego di strumenti digitali quali SMS, mail o WhatsApp ha comunque spazio maggiore in tale ambito di comunicazione rispetto a quello rivolto al paziente. Im-

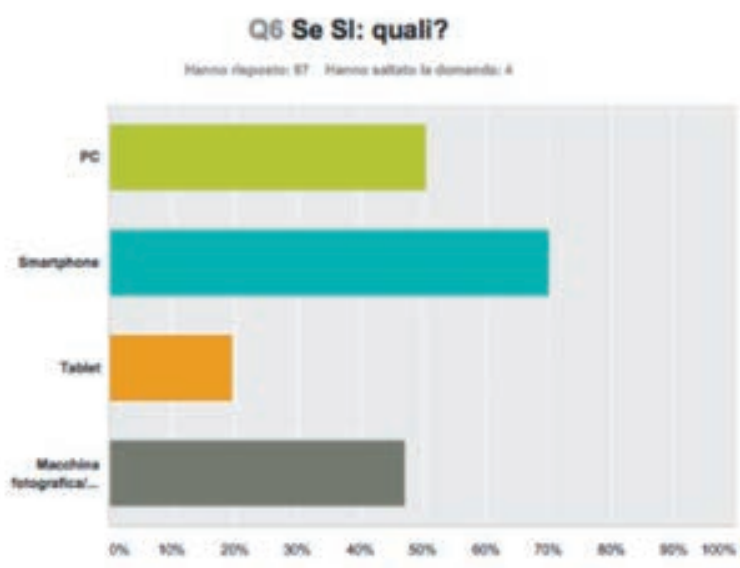

Figura 3.

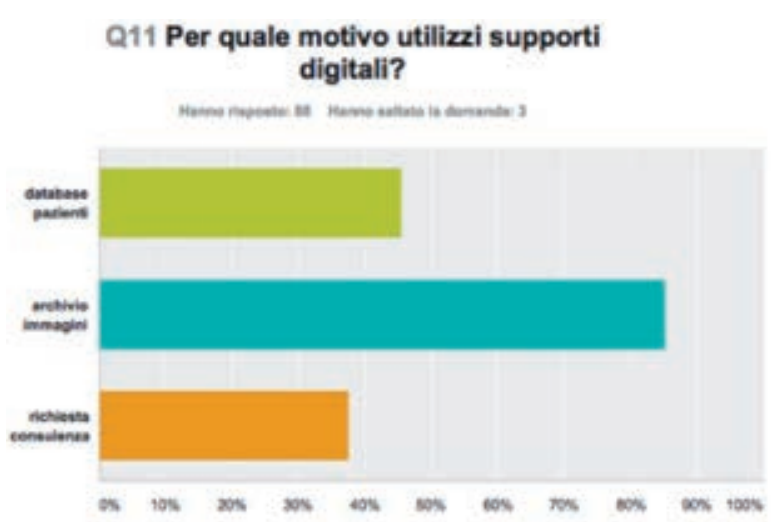

Figura 4. portante considerare che una parte (meno del $10 \%$ ) utilizza ancora la tradizionale comunicazione "cartacea" (Figura 6).

In più del $90 \%$ dei casi non vengono utilizzate piattaforme digitali dedicate alla telemedicina per comunicare dati clinici, ma modalità (come quelle indicate in precedenza) altrimenti utilizzate per altri scopi, anche di tipo personale (Figura 7).

Circa 1'85\% dei partecipanti riesce a documentare la

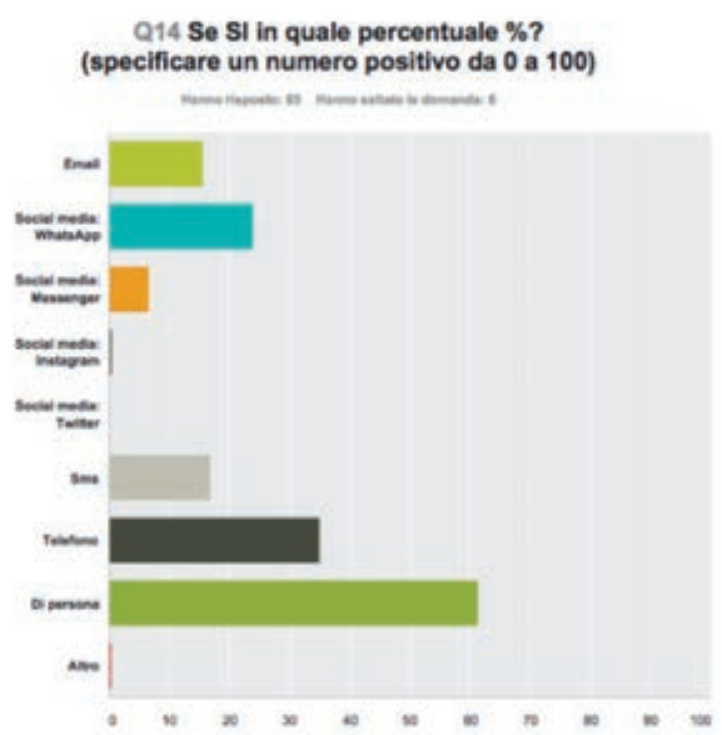

Figura 5.

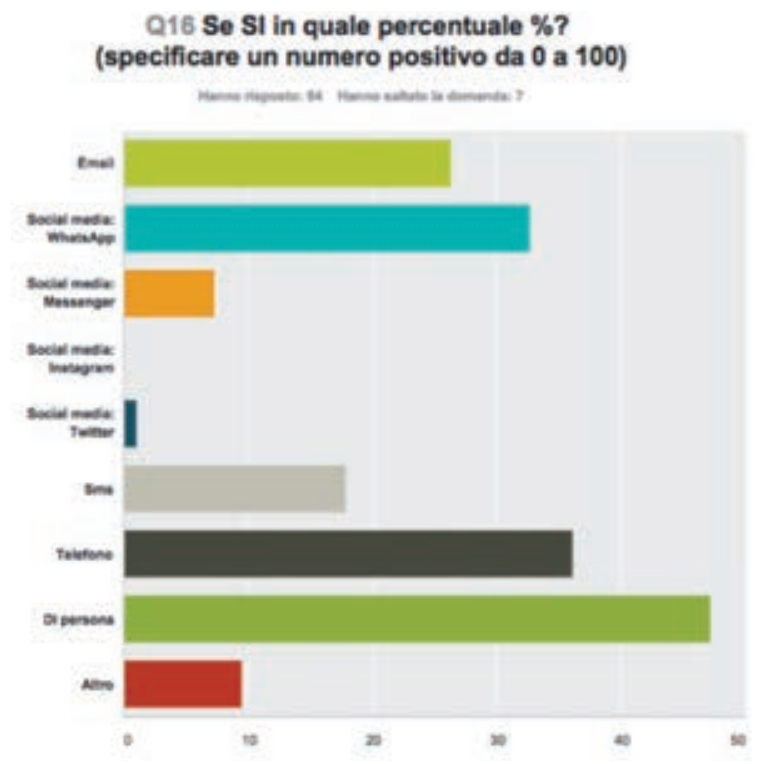

Figura 6. 


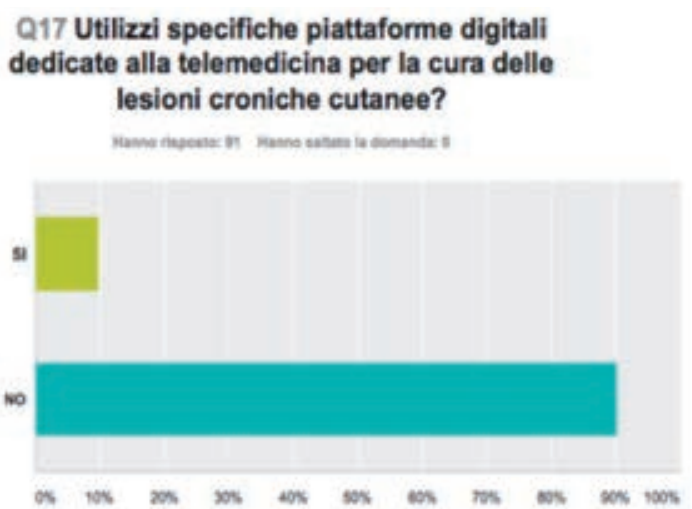

Figura 7.

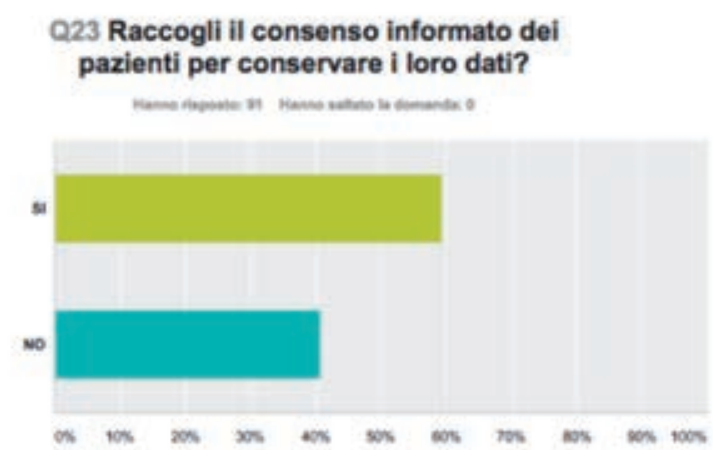

Figura 8.

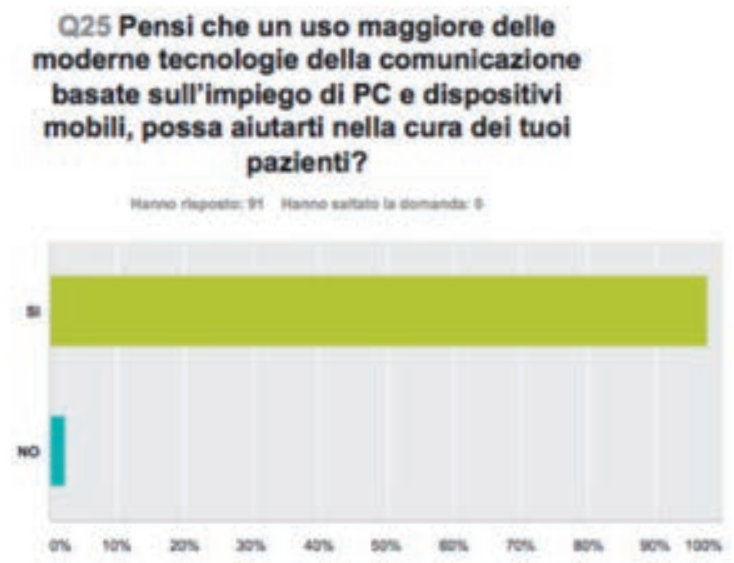

Figura 9. progressione della guarigione delle LCC a loro affidate utilizzando una valutazione sulle fotografie senza effettuare, tuttavia, specifiche misurazioni.

In circa il 90\% dei casi, gli operatori non hanno strumenti per documentare i costi di gestione della cura delle stesse LCC.

Il consenso informato alla gestione dei dati clinici è raccolto in circa il $60 \%$ dei casi, per lo più $(80 \%)$ archiviandone una copia cartacea (Figura 8).

Quasi tutti i partecipanti sono convinti che un uso maggiore delle moderne tecnologie digitali della comunicazione possa aiutarli a gestire meglio la cura dei pazienti affetti da LCC (Figura 9).

\section{CONCLUSIONI}

I partecipanti alla survey hanno mostrato un approccio tradizionale utilizzando prevalentemente strumenti di tipo classico come le cartelle di tipo cartaceo o digitale (su pc).

È evidente, tuttavia, l'interesse per le nuove tecnologie: sicuramente non avere strumenti dedicati al lavoro ne riduce l'impiego, ma mostra in coloro che, nonostante tutto, li utilizzano la reale convinzione che tali mezzi siano utili per migliorare la loro attività clinica, permettendogli - almeno - di risparmiare tempo.

L'archiviazione delle immagini cliniche digitali e la possibilità di scambiarle in modo molto rapido rappresenta, probabilmente, l'aspetto più accattivante delle moderne tecnologie. Ciò è perfettamente in linea con i moderni e più diffusi atteggiamenti culturali, ma espone a notevoli rischi di scarsa protezione di tali dati sensibili. La insufficiente diffusione di piattaforme digitali dedicate alla telemedicina determina, infatti, una commistione di dati clinici e personali soprattutto sui dispositivi personali portatili, con la impossibilità a rispettarne la riservatezza come vorrebbero le regole sulla tutela della privacy dei pazienti.

La raccolta del consenso informato alla gestione dei dati clinici soltanto nel $60 \%$ dei casi dimostra, in ogni caso, una tendenza a non conformarsi alle norme vigenti su questo argomento.

Importante è la constatazione della mancanza di diffusione di strumenti utili per la valutazione obiettiva delle variazioni morfologiche delle LCC, di immediato impiego per i clinici, e di strumenti che permettano la archiviazione e la valutazione dei loro costi di gestione, utilizzabili anche dagli amministratori.

I risultati di questa indagine conoscitiva consentono di concludere che vi è un'esigenza diffusa, nel mondo del Wound Care, di strumenti "moderni" e "smart" che permettano di migliorare e vivacizzare questo tipo di attività clinica. 